\title{
Dare to Care: patients with advanced cancer and their informal caregivers want personal well-organized care
}

Janneke van Roij ${ }^{16}$ | j.vanroij@iknl.nl , Bibi de Zeeuw ${ }^{16}$, Myrte Zijlstraa ${ }^{16}$, Niels Claessens ${ }^{4}$, Natasja Raijmakers ${ }^{16}$, Lonneke van de Poll-Franse ${ }^{125}$, Linda Brom ${ }^{16}$ 1 The Netherlands Comprehensive Cancer Organisation, Utrecht; ${ }^{2}$ CoRPS - Center of Research on Psychology in Somatic diseases, Department of Medical and Clinical Psychology, Tilburg University, Tilburg; ${ }^{3}$ Department of Medical oncology, Maxima Medical Centre, Eindhoven; ${ }^{4}$ Department of Pulmonology, Rijnstate, Nijmegen; ${ }^{5}$ Division of Psychosocial Research and Epidemiology, The Netherlands Cancer Institute, Amsterdam; ${ }^{6}$ Association for Palliative Care in the Netherlands (PZNL), Utrecht; the Netherlands

\section{PURPOSE}

Palliative care is focussed on improving quality of life of patients with a life-threatening illness and their informal caregivers. It remains unclear what good quality of care entails for patients with advanced cancer and their informal caregivers. Therefore, the aim of this study is to explore the essential aspects of palliative care according to patients with advanced cancer and their informal caregivers.

\section{METHODS}

Seven focus groups and seven in-depth semi-structured interviews with 18 patients suffering from advanced cancer and 15 informal caregivers were conducted in the Netherlands. All interviews were audiotaped, transcribed verbatim, and open coded using a thematic analysis approach.

\begin{tabular}{|c|c|c|c|c|}
\hline & & & Patients $(n=18)$ & $\begin{array}{l}\text { formal } \\
\text { ivers }(n=15)\end{array}$ \\
\hline Gender & \multicolumn{2}{|l|}{ Male } & $9(50 \%)$ & $6(40 \%)$ \\
\hline Age & \multicolumn{2}{|l|}{ Mean (range) } & 59 years $(38-76)$ & 58 years $(40-76)$ \\
\hline Education & \multicolumn{2}{|c|}{$\begin{array}{l}\text { Low education } \\
\text { Middle education } \\
\text { High education } \\
\text { Missing }\end{array}$} & $\begin{array}{c}2(11 \%) \\
6(33 \%) \\
9(50 \%) \\
1(6 \%)\end{array}$ & $\begin{array}{l}4(27 \%) \\
8(53 \%) \\
3(20 \%) \\
-\end{array}$ \\
\hline $\begin{array}{l}\text { Primary cancer } \\
\text { site in patients }\end{array}$ & \multicolumn{2}{|l|}{$\begin{array}{l}\text { Lung } \\
\text { Colorectal } \\
\text { Breast } \\
\text { Oesophagus } \\
\text { Prostate }\end{array}$} & $\begin{array}{l}8(44 \%) \\
6(33 \%) \\
2(11 \%) \\
1(6 \%) \\
1(6 \%)\end{array}$ & $\begin{array}{c}73 \%(11) \\
7 \%(1) \\
13 \%(2) \\
7 \%(1) \\
-\end{array}$ \\
\hline $\begin{array}{l}\text { Relation with } \\
\text { patient }\end{array}$ & \multicolumn{2}{|l|}{$\begin{array}{l}\text { Partner } \\
\text { Daughter } \\
\text { Friend }\end{array}$} & $\begin{array}{c}12 \\
2 \\
1\end{array}$ & $\begin{array}{c}12(80 \%) \\
2(13 \%) \\
1(7 \%) \\
\end{array}$ \\
\hline Main domain & Subtheme & $\mathrm{Ca}$ & gory & $\begin{array}{c}\text { Mentioned } \\
\text { by* }\end{array}$ \\
\hline \multirow{7}{*}{$\begin{array}{l}\text { Communication } \\
\text { \& Relation }\end{array}$} & \multirow{2}{*}{$\begin{array}{l}\text { Personal } \\
\text { engagement }\end{array}$} & Pat & nt-physician match & $p, c$ \\
\hline & & & g unique & $p$ \\
\hline & \multirow{5}{*}{$\begin{array}{l}\text { Prerequisites of } \\
\text { good } \\
\text { communication }\end{array}$} & $\ln v$ & tory of mood & c \\
\hline & & & $\begin{array}{l}\text { athic delivery of } \\
\text { nostics }\end{array}$ & $p, c$ \\
\hline & & Unc & rstand concept of hope & $p, c$ \\
\hline & & & ower via humour & $p, c$ \\
\hline & & & $\begin{array}{l}\text { ss involvement in } \\
\text { ion making }\end{array}$ & $p, c$ \\
\hline \multirow{7}{*}{$\begin{array}{l}\text { Organisation } \\
\text { of care }\end{array}$} & \multirow{2}{*}{$\begin{array}{l}\text { Patient-centred } \\
\text { logistics }\end{array}$} & $\begin{array}{l}\text { Pre } \\
\text { sch }\end{array}$ & $\begin{array}{l}\text { ctability regarding } \\
\text { dules \& procedures }\end{array}$ & $p$ \\
\hline & & & $\begin{array}{l}\text { personal preferences into } \\
\text { unt }\end{array}$ & $p, c$ \\
\hline & \multirow{3}{*}{$\begin{array}{l}\text { Continuity of } \\
\text { care }\end{array}$} & Wh & is in charge? & $p, c$ \\
\hline & & $\mathrm{Ne}$ & for a care coordinator & p, c \\
\hline & & & $\begin{array}{l}\text { ily availability of health } \\
\text { professionals }\end{array}$ & $p, c$ \\
\hline & \multirow{2}{*}{$\begin{array}{l}\text { Monitoring } \\
\text { supportive care } \\
\text { needs }\end{array}$} & $\begin{array}{l}\text { Att } \\
\text { asp }\end{array}$ & $\begin{array}{l}\text { tion for psychological } \\
\text { cts of disease }\end{array}$ & $p, c$ \\
\hline & & & ssibility & $p, c$ \\
\hline
\end{tabular}

\section{RESULTS}

Two essential aspects of quality of care from the patients' and informal caregivers' perspective arose: 'communication and relation' and 'organization of care'. Regarding communication and relation, patients and informal caregivers found it essential that health care professionals were personally engaged and provided support and compassion. Regarding organization of care, patients and informal caregivers expressed the importance of well-organized logistics tailored to needs of the receiver. Patients and informal caregivers expressed the importance of supportive care being offered multiple times during the disease trajectory.

\section{DISCUSSION}

This study shows that it is important for patients with advanced cancer and their informal caregivers that health care professionals are personally engaged and care is patient-centred organised and coordinated. To optimise quality of care, it is of utmost importance that health care professionals have good communication skills and explore the patients' and informal caregivers' unique experiences, needs, preferences, and expectations.

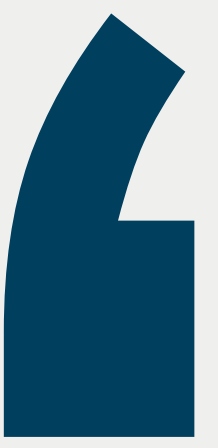

"Yes, but in a situation like ours, you really need an empathetic doctor who understands how you are feeling, has a real interest in you and is there for you when you need them." (P4-FG).

"Because you are undergoing an operation, they discover that all that chemo has made you develop a heart rhythm disorder, so you end up in the cardiac circuit, then the urological circuit, then the neurology circuit, then the oncological circuit. You need someone who knows everything about you. And you try to tell the GP about it, but they don't have enough information." (P31-FG).

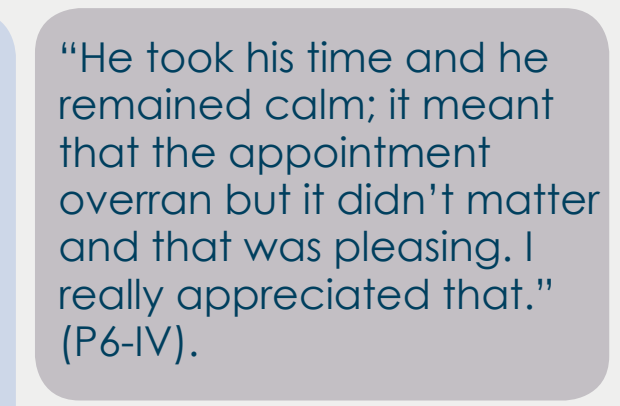

"I was once asked if I wanted to talk to someone, if I needed further help with anything at all. But it never really came to anything much. And sometimes I think to myself, maybe it should be now, now should be now, now all straight in my mind, maybe they should offer it again." (P3-IV).
"yes but even if you knew, things could still change on the day that you came. Someone's chemo could have finished earlier and then that chair would have been free, so you could have got started, instead of in that room on that bed. [...] I understood that. But it does give you more peace of mind, because there are so many other things to think about, then it gives you more peace of mind because you don't have to think about it" (P3-IV).

\section{tion}

(1)

